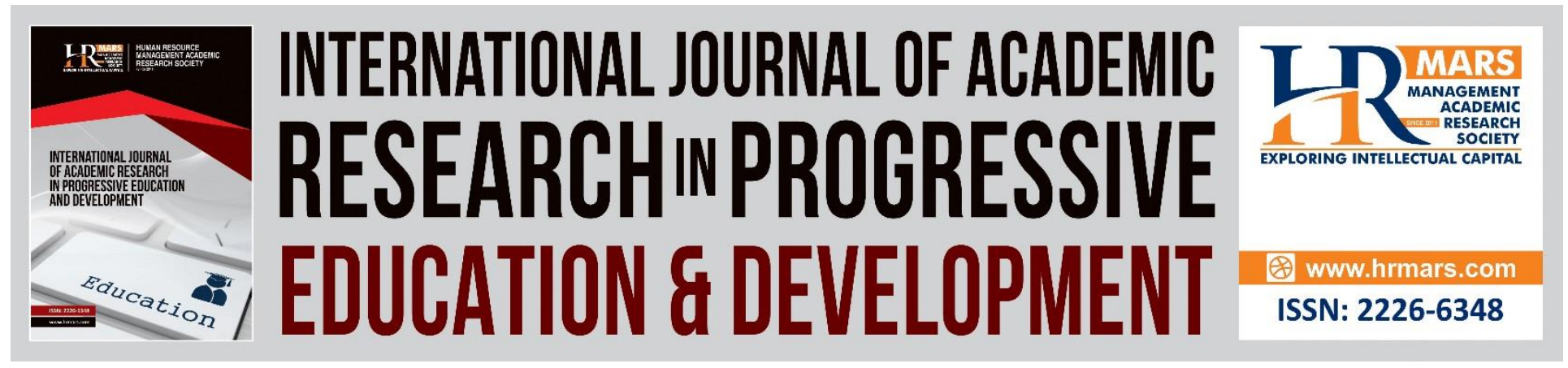

\title{
The Malaysia Fitness Facility Grading Scale (MFFGS) Instrumentation Development
}

Ellail Ain Mohd Aznan, Jaffry Zakaria, Nur Ikhwan Mohamad

To Link this Article: http://dx.doi.org/10.6007/IJARPED/v10-i3/10629 ～DOI:10.6007/IJARPED/v10-i3/10629

Received: 11 June 2021, Revised: 16 July 2021, Accepted: 29 July 2021

Published Online: 25 August 2021

In-Text Citation: (Aznan et al., 2021)

To Cite this Article: Aznan, E. A. M., Zakaria, J., \& Mohamad, N. I. (2021). The Malaysia Fitness Facility Grading Scale (MFFGS) Instrumentation Development. International Journal of Academic Research in Progressive Education and Development, 10(3), 350-360.

Copyright: (C) 2021 The Author(s)

Published by Human Resource Management Academic Research Society (www.hrmars.com)

This article is published under the Creative Commons Attribution (CC BY 4.0) license. Anyone may reproduce, distribute, translate and create derivative works of this article (for both commercial and non-commercial purposes), subject to full attribution to the original publication and authors. The full terms of this license may be seen at: http://creativecommons.org/licences/by/4.0/legalcode

Vol. 10(3) 2021, Pg. 350 - 360

http://hrmars.com/index.php/pages/detail/IJARPED JOURNAL HOMEPAGE

Full Terms \& Conditions of access and use can be found at http://hrmars.com/index.php/pages/detail/publication-ethics 


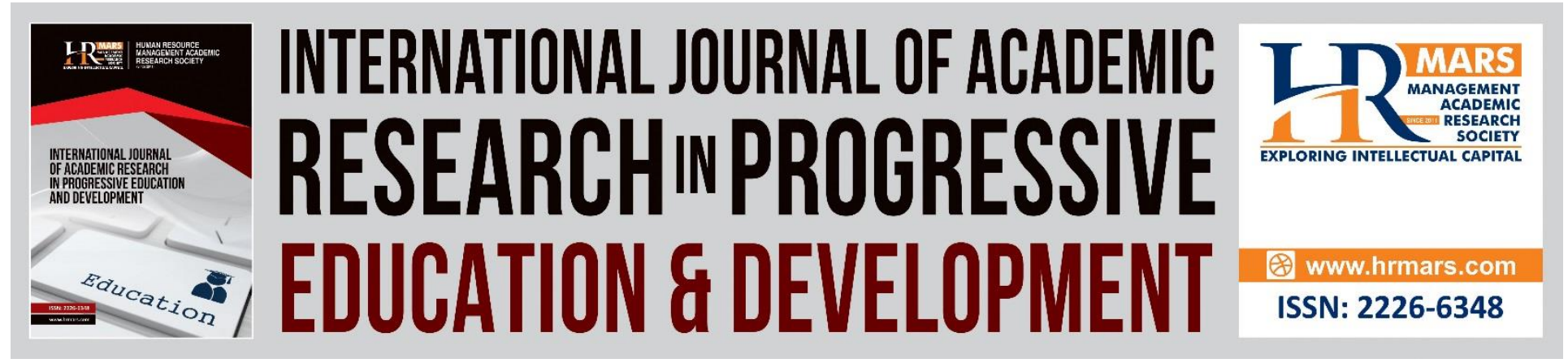

\title{
The Malaysia Fitness Facility Grading Scale (MFFGS) Instrumentation Development
}

\author{
Ellail Ain Mohd Aznan ${ }^{1,2}$, Jaffry Zakaria², Nur Ikhwan Mohamad² \\ ${ }^{1}$ Faculty of Sports Science and Recreation, Universiti Teknologi MARA, Cawangan Perlis, Kampus \\ Arau, 02600 Arau, Perlis, Malaysia, ${ }^{2}$ Faculty of Sport Science and Coaching, Universiti \\ Pendidikan Sultan Idris, 35900 Tanjung Malim Perak \\ Email: ${ }^{1}$ ellailain@uitm.edu.my, ${ }^{2}$ jaffry@fsskj.upsi.edu.my, ${ }^{2}$ nur.ikhwan@fsskj.upsi.edu.my
}

\begin{abstract}
The purpose of this study was to develop and validate the Malaysia Fitness Facility Grading SCALE (MFFGS). To assess the characteristics of good fitness facilities, thirty-three items were established, separated by dimensions. Based on the dimension of a good fitness facility, the instrument was designed through a comprehensive literature research and focus group discussion. The questionnaire was applied as a cross-sectional study and data were collected as establishing factors to confirm and ascertain construct validity. Reliability was tested by measuring internal consistency. Through a rigorous literature study and empirical evidence, the constructs were confirmed. The validity of this MFFGS will aid future studies evaluating the quality of a fitness facility's services. This tool can help academics gain a more comprehensive and in-depth understanding of an excellent fitness facility and encourage future research into its possibilities.

Keywords: Malaysia Fitness Facility Grading Scale (MFFGS), Fitness Facility, Instrumentation

\section{Introduction}

In developing a successful or a good fitness facility, which the developer needs to understand the safety and the building constructions requirement for a fitness facility. Setting up a new facility would not be an easy task, to develop a new facility, there are so many criteria and requirements that need to be fulfilled. Nowadays the fitness industry had emerged and evolve to a new level, report from the International Health, Racquet and Sportsclub Association (IHRSA) in 2016, the global health club industry revenue has reached to 83.1 billion U.S dollar, which equals to 162.1 million members visited 201,000 clubs. The United State of America (USA) has the leads of the health and fitness industry with the totaled revenue is 27.6 billion U.S dollar. The evolution was expected on 2017 and according to IHRSA report on 2017, global health club industry revenue totaled 87.2 billion U.S dollar.
\end{abstract}


Similarly, Malaysia was not excluded from this evolution of the fitness industry. According to the Department of Statistics Malaysia, the total revenue in the area of arts, entertainment, sports, and recreation for 2017 is RM 20 billion which had been increased from RM 15.8 billion in 2010. Correspondingly, Ong (2015) stated that Malaysian are now aware of the need to stay healthy in a stressful environment which is seeming to be happening nowadays. Through the experience and in contrary to the issue, more Malaysian are involving and getting into the fitness industry, they are engaging in the physical and fitness activities specified by the increment in the gym membership (Ong \& Yap, 2017). In addition, the fitness industry in Malaysia had become a battlefield with the evolution of fitness centers and fitness facilities (Ong, 2015). Yusof, Joseph, and Shah (2017) mentioned that Malaysia's health and fitness industry had tremendous growth, especially in interest and participation.

Cianfanelli et al (2016) mentioned that different countries have different approaches in operating and maintaining the facilities. As an example, most sporting facilities in Australia are operated and maintained by local governments, schools (both public and private), and private sector business institutions which include sporting organizations or various commercial operators (Cianfanelli et al., 2016). Importantly, this issue was also related to the developed fitness facilities. The facilities must be accordingly followed the requirement by the legal. Undoubtedly, safety and quality in sports environments are the most crucial elements that should not be simply abandoned. This safety and quality in sports environments should be ruled by regulations and supported by monitoring tools (Cianfanelli et al., 2016). Ranking or grading can be very important especially in the area that involves the life and safety of the public. Grading schemes have become a popular way to convey the quality of public services accessibly and concisely (Meltzer et al., 2015).

According to Thaler \& Sunstein (2009), the grading system is one of a goof information-based policy that aimed to influence and persuade the behavior or direction of a user either directly or indirectly. Meltzer et.al (2015), also mentioned that grading is also conveying information upon the quality of services or goods including the policies, public education, and public health. In addition, this grading system will help in improving the quality of services and goods, for example, many school districts grade public schools on their effectiveness (specifical improvements in test scores and other metrics), and they make these grades available to the public.

Therefore, it is suggested that the same methods were applied. The needs of the standard grading system are needed crucially in the fitness industry as it keeps on evolving. In developing the standard grading system for fitness facilities in Malaysia, it is important to have the specialist in each area which includes the facility or building contractors, the risk management specialist, the governed body for building and facilities, and the stakeholders. Besides that, the previous study will also be used in determining the important items in grading or classifying the fitness facilities as standard and safe facilities to be used by the public.

Through this study, the Malaysia Fitness Facility Grading System (MFFGS) was developed and validated to meet the requirement on assessing a good fitness facility, this instrument may assist in gaining information on the established fitness facility especially in Malaysia. Additionally, this instrument can also be applied for the fitness industry in Asian and Western. 


\section{Methodology}

The MFFGS had been developed by four main phases which include the conceptualization, validity, reliability, and model specification. A total of 50 respondent completed the pilot study in developing the MFFGS. All the respondents completed the questionnaire voluntarily. The study held from May 2021 - June 2021.

\section{Results}

\section{Conceptualization}

The first stage in building a novel instrument, as shown in Figure 1, is to generate a conceptual characterization of the construct. The construct was developed through a thorough systematic literature review and focus group discussion with the stakeholders and the experts from the fitness industry. Atkin and Brooks (2015) mentioned that there are few dimensions that can be considered in determining a good facility, these includes, human resource management, facility development, facility administration, safety and risk management and information, communication, and technology. Accordingly, the ACSM's Health and Fitness Facility Standards and Guidelines were also referring to similar dimensions. The dimensions were believed to give an impact on the established fitness facility and affecting the quality provided to the customers. The human resources management was believed to serve a good relationship between the fitness facilities developer and the staff as it will affect the staff reaction towards the customer. Facility development concern with the spaces, signages, other facilities provided, and the arrangement of the equipment in providing a conducive environment to the customer while working out. Facility administration focusing more on the qualification of the staff and the services provided by the fitness facilities which also include the membership and the professionalism of the staff. Safety and risk management can be considered as the most important dimension as this will be reflecting on the capability of the fitness facility in handling injuries or any emergency cases. The last dimension is reflecting towards the current trend which most of the documentation were no longer printed out and e-filing were acknowledged for a better, effective, and green environment. This dimension also suggests the availability of technology enhancement by the fitness operator especially in conducting virtual class and emarketing through social media.

\section{Validity}

The construct developed need to be analyze for validity, basically there are thirty-three items constructed segregated by factors, Human Resource (HR) six items, Facility Development (FD) nine items, Facility Administration (FA) eight items, Safety and Risk Management (SM) five items, and Information, communication, and Technology (ICT) five items. Table 1 demonstrates the content adequacy through the Rotated Component Matrix, the results shows that all constructs were accepted and valid by measure of component value more than .40 by demanded factor. 
Table 1: Rotated Component Matrix

\begin{tabular}{|c|c|c|c|c|c|c|}
\hline \multirow{2}{*}{ Coding } & \multirow{2}{*}{ Items } & \multicolumn{5}{|c|}{ Component } \\
\hline & & 1 & 2 & 3 & 4 & 5 \\
\hline HR1 & $\begin{array}{l}\text { 1.The fitness facility had provided the basic services to } \\
\text { enhance the staff emotional intelligence/Pihak fasiliti } \\
\text { kecergasan telah menyediakan kemudahan asas bagi } \\
\text { meningkatkan kecerdasan emosi para kakitangan. }\end{array}$ & .690 & .065 & -.032 & .138 & .199 \\
\hline HR2 & $\begin{array}{l}\text { 2.The fitness facilities had provided a good working } \\
\text { environment to enhance the job satisfaction among the } \\
\text { staff/Pihak fasiliti kecergasan ini telah menyediakan } \\
\text { suasana kerja yang baik bagi meningkatkan kepuasan } \\
\text { kerja dalam kalangan kakitangan. }\end{array}$ & .681 & .241 & .290 & .132 & .135 \\
\hline HR3 & $\begin{array}{l}\text { 3.The fitness facilities provide a training session for all } \\
\text { the staff to increase the level of services provided to the } \\
\text { customers/Pihak fasiliti kecergasan menyediakan sesi } \\
\text { latihan kepada semua kakitangan bagi meningkatkan } \\
\text { tahap perkhidmatan kepada para }\end{array}$ & .726 & .163 & .082 & .197 & .251 \\
\hline HR4 & $\begin{array}{l}\text { 4.The fitness facility had provided a feedback forms to } \\
\text { improve the services/Pihak fasiliti kecergasan } \\
\text { menyediakan borang maklumbalas bagi meningkatkan } \\
\text { tahap perkhidmatan. }\end{array}$ & .531 & .507 & .119 & .371 & .165 \\
\hline HR5 & $\begin{array}{l}\text { 5.The fitness facility is providing the competent staff } \\
\text { based on their skills, knowledge, and certification to } \\
\text { increase the customer's loyalty and trust/ Pihak fasiliti } \\
\text { kecergasan menyediakan kakitangan yang } \\
\text { berkemampuan berdasarkan kemahiran, pengetahua }\end{array}$ & .707 & .347 & .086 & .099 & .408 \\
\hline HR6 & $\begin{array}{l}\text { 6.The fitness facilities provide full support and trust to } \\
\text { the staff whenever they are dealing with the } \\
\text { customers/Pihak fasiliti kecergasan memberikan } \\
\text { sokongan dan kepercayaan penuh kepada kakitangan } \\
\text { ketika berhadapan dengan pelanggan. }\end{array}$ & .599 & .206 & .213 & .353 & .332 \\
\hline FD1 & $\begin{array}{l}\text { 7.The fitness facilities arrangement of equipment is easy } \\
\text { to be accessed/ Susun atur peralatan di dalam fasiliti } \\
\text { kecergasan ini mudah diakses. }\end{array}$ & .136 & .700 & .410 & .142 & .237 \\
\hline FD2 & $\begin{array}{l}\text { 8.The fitness facilities had provided a conducive workout } \\
\text { station and spaces which always cleaned and well } \\
\text { maintained/Fasiliti kecergasan ini menyediakan ruang } \\
\text { senaman yang kondusif yang sentiasa bersih dan dijaga } \\
\text { rapi. }\end{array}$ & .182 & .566 & .424 & .486 & .109 \\
\hline
\end{tabular}




\begin{tabular}{|c|c|c|c|c|c|c|}
\hline FD3 & $\begin{array}{l}\text { 9.The staff are always being friendly which make the } \\
\text { customers feels valued and welcomed/Para kakitangan } \\
\text { sentiasa bersikap ramah membuatkan para pelanggan } \\
\text { merasa dihargai dan disambut baik. }\end{array}$ & .043 & .812 & .084 & .268 & .145 \\
\hline FD4 & $\begin{array}{l}\text { 10.The fitness facilities provided a convenient parking } \\
\text { places to enhance customers accessibility/Pihak fasiliti } \\
\text { kecergasan menyediakan tempat letak kenderaan yang } \\
\text { selesa yang memberikan kemudahan kepada para } \\
\text { pelanggan. }\end{array}$ & -.002 & .544 & -.077 & .373 & .510 \\
\hline FD5 & $\begin{array}{l}\text { 11. The fitness facilities had provided a clear signage for } \\
\text { each equipment and services provided/Pihak fasiliti } \\
\text { kecergasan menyediakan papan tanda yang jelas untuk } \\
\text { setiap peralatan dan kemudahan yang disediakan. }\end{array}$ & .171 & .616 & .372 & .329 & .053 \\
\hline FD6 & $\begin{array}{l}\text { 12.The fitness facilities provided a clear access route and } \\
\text { entrance area for customer's accessibility/Pihak fasiliti } \\
\text { kecergasan menyediakan laluan keluar masuk yang } \\
\text { selesa kepada para pelanggan. }\end{array}$ & .235 & .832 & .071 & .088 & .052 \\
\hline FD7 & $\begin{array}{l}\text { 13.The fitness facilities also provided others } \\
\text { accommodations (i.e. : sauna, bathrooms, spas and etc) } \\
\text { which enhance customer's satisfaction towards the } \\
\text { fitness facilities services/Pihak fasiliti kecergasan } \\
\text { menyediakan kemudahan lain (i.e. : sauna, bilik }\end{array}$ & .435 & .502 & .151 & -.066 & .439 \\
\hline FD8 & $\begin{array}{l}\text { 14.The fitness facilities have provided modern and up- } \\
\text { to-date equipment/Fasiliti kecergasan ini menyediakan } \\
\text { peralatan yang moden dan terkini. }\end{array}$ & .134 & .400 & .363 & .378 & .345 \\
\hline FD9 & $\begin{array}{l}\text { 15.The fitness facilities provided their physical facilities } \\
\text { (shelves, counters, fridges, computer, lights) to be } \\
\text { visually appealing to the customers/Pihak fasiliti } \\
\text { kecergasan menyediakan fasiliti fizikal (almari, kaunter, } \\
\text { peti ais, computer dan lampu) u }\end{array}$ & .167 & .536 & .431 & .302 & .258 \\
\hline FA1 & $\begin{array}{l}\text { 16. The staff are always well dressed and appear neat } \\
\text { when dealing with the customers/Para kakitangan } \\
\text { sentiasa berpakaian kemas apabila berhadapan dengan } \\
\text { pelanggan. }\end{array}$ & .316 & .283 & .785 & .158 & .027 \\
\hline FA2 & $\begin{array}{l}\text { 17. The staff are always helpful whenever the customers } \\
\text { are in need/ Para kakitangan sentiasa memberikan } \\
\text { bantuan kepada pelanggan ketika perlu. }\end{array}$ & .214 & .447 & .541 & .112 & -.178 \\
\hline FA3 & $\begin{array}{l}\text { 18.The staff always give prompt services to the } \\
\text { customers/Para kakitangan sentiasa memberikan } \\
\text { perkhidmatan yang segera kepada para pelanggan. }\end{array}$ & .370 & .250 & .520 & .429 & -.101 \\
\hline
\end{tabular}




\begin{tabular}{|c|c|c|c|c|c|c|}
\hline FA4 & $\begin{array}{l}\text { 19.The staff in the fitness facilities are professionally } \\
\text { certified/ Kakitangan di fasiliti kecergasan ini } \\
\text { mempunyai kelayakan professional. }\end{array}$ & .251 & .307 & .733 & .135 & .297 \\
\hline FA5 & $\begin{array}{l}\text { 20.The staffs in the fitness facilities can give clear } \\
\text { instruction during any activities/exercises performed/ } \\
\text { Kakitangan di fasiliti kecergasan ini mampu memberikan } \\
\text { arahan dengan baik ketika aktiviti/latihan dijalankan. }\end{array}$ & .355 & .207 & .815 & .150 & .092 \\
\hline FA6 & $\begin{array}{l}\text { 21. The fitness facilities take a serious action towards any } \\
\text { complaints/report/feedback from the client/customer / } \\
\text { Pihak fasiliti kecergasan mengambil maklum setiap } \\
\text { aduan/maklumbalas daripada pelanggan. }\end{array}$ & .367 & .487 & .559 & .246 & .141 \\
\hline FA7 & $\begin{array}{l}\text { 22. The fitness facilities had provided an interview in } \\
\text { determining the qualified staff/ Pihak fasiliti kecergasan } \\
\text { melakukan saringan temuduga bagi mengenalpasti } \\
\text { kakitangan yang berkelayakan. }\end{array}$ & -.015 & .491 & .623 & .217 & .354 \\
\hline FA8 & $\begin{array}{l}\text { 23.The fitness facilities provide a good salary and } \\
\text { benefits to all the staff Pihak fasiliti kecergasan telah } \\
\text { menyedikan tawaran gaji dan faedah yang baik kepada } \\
\text { kakitangan. }\end{array}$ & .387 & .327 & .522 & .005 & .346 \\
\hline SRM1 & $\begin{array}{l}\text { 24.The fitness facilties had provided an emergency } \\
\text { procedure flow chart for the client/customer/ Pihak } \\
\text { fasiliti kecergasan telah menyediakan carta alir prosedur } \\
\text { kecemasan kepada pelanggan. }\end{array}$ & .282 & .212 & .516 & .648 & .011 \\
\hline SRM2 & $\begin{array}{l}\text { 25.The fitness facilities staff had briefed the } \\
\text { customer/client of possible risk for each } \\
\text { activities/exercises/ Kakitangan di fasiliti kecergasan } \\
\text { telah menerangkan tentang risiko yang bakal berlaku } \\
\text { pada setiap aktiviti/ latihan. }\end{array}$ & .205 & .289 & .204 & .728 & .001 \\
\hline SRM3 & $\begin{array}{l}\text { 26. The fitness facilities had provided a secure } \\
\text { emergency area for any light to moderate injury to be } \\
\text { treated/ Pihak fasiliti kecergasan telah menyediakan } \\
\text { ruang kecemasan khas bagi melakukan rawatan awal } \\
\text { kepada kecederaan biasa dan sederhana. }\end{array}$ & .168 & .253 & .081 & .836 & .081 \\
\hline SRM4 & $\begin{array}{l}\text { 27.The staff in the fitness facilities are provided with } \\
\text { first aid certificates/ Kakitangan di fasiliti kecergasan ini } \\
\text { mempunyai sijil rawatan bantu mula }\end{array}$ & -.137 & .250 & .339 & .638 & .207 \\
\hline SRM5 & $\begin{array}{l}\text { 28.The fitness facilities had provided secure locker area } \\
\text { with CCTV for the customer/client belonging / Pihak } \\
\text { fasiliti kecergasan telah menyediakan ruang } \\
\text { penyimpanan khas dengan pantauan CCTV untuk } \\
\text { barangan peribadi pelanggan. }\end{array}$ & .065 & .001 & .191 & .564 & .537 \\
\hline
\end{tabular}




\begin{tabular}{|c|c|c|c|c|c|c|}
\hline ICT1 & $\begin{array}{l}\text { 29.The fitness facilities had provided an online } \\
\text { registration form for the new members/ Pihak fasiliti } \\
\text { kecergasan telah menyediakan borang pendaftaran ahli } \\
\text { baharu secara atas talian }\end{array}$ & .537 & .329 & .107 & .255 & .629 \\
\hline ICT2 & $\begin{array}{l}\text { 30.The fitness facilities own a website that provides } \\
\text { information for the client/customer/ Pihak fasiliti } \\
\text { kecergasan telah menyediakan satu laman web bagi } \\
\text { menyalurkan maklumat kepada para pelanggan. }\end{array}$ & .361 & .241 & .348 & .042 & .773 \\
\hline ICT3 & $\begin{array}{l}\text { 31.The fitness facilities had established the e-filing } \\
\text { system for all transactions and membership records/ } \\
\text { Pihak fasiliti kecergasan telah menggunakan sistem e- } \\
\text { filing bagi menyimpan setiap rekod transaksi dan } \\
\text { keahlian. }\end{array}$ & .420 & .224 & .135 & .143 & .594 \\
\hline ICT4 & $\begin{array}{l}\text { 32. The fitness facilities optimize the use of technology } \\
\text { for virtual class for the client/customer/ Pihak fasiliti } \\
\text { kecergasan menggunakan teknologi secara optimum } \\
\text { bagi penganjuran kelas secara maya kepada pelanggan. }\end{array}$ & .445 & .413 & .223 & .057 & .624 \\
\hline ICT5 & $\begin{array}{l}\text { 33.The fitness facilities had a good networking and } \\
\text { communication with the client/customer in the virtual } \\
\text { world/ Pihak fasiliti kecergasan mempuyai rangkaian dan } \\
\text { komunikasi yang baik bersama pelanggan di dunia maya. }\end{array}$ & .459 & .353 & .104 & .088 & .659 \\
\hline
\end{tabular}

Extraction Method: Principal Component Analysis.

Rotation Method: Varimax with Kaiser Normalization.

a. Rotation converged in 17 iterations.

\section{Reliability}

Table 2 represents the reliability. Reliability for each scale was analyzed by measuring Cronbach's alpha for each of the sub-dimensions and was well above the 0.7 threshold, ranging from 0.88 to 0.97. Therefore, the construct was reliable.

Table 2: Reliability Statistic

\begin{tabular}{|l|r|r|r|}
\hline \multicolumn{1}{|c|}{ Items } & Cronbach's Alpha & Cronbach's Alpha Based on Standardized Items & N of Items \\
\hline OVERALL & .968 & .968 & 33 \\
\hline HRM & .849 & .851 & 6 \\
\hline FD & .883 & .891 & 9 \\
\hline FA & .926 & .928 & 8 \\
\hline SRM & .876 & .878 & 5 \\
\hline ICT & .903 & .908 & 5 \\
\hline
\end{tabular}


INTERNATIONAL JOURNAL OF ACADEMIC RESEARCH IN PROGRESSIVE EDUCATION AND DEVELOPMENT

Vol. 10, No. 3, 2021, E-ISSN: 2226-6348 @ 2021 HRMARS

FIGURE 1: GOOD FITNESS FACILITY MODEL

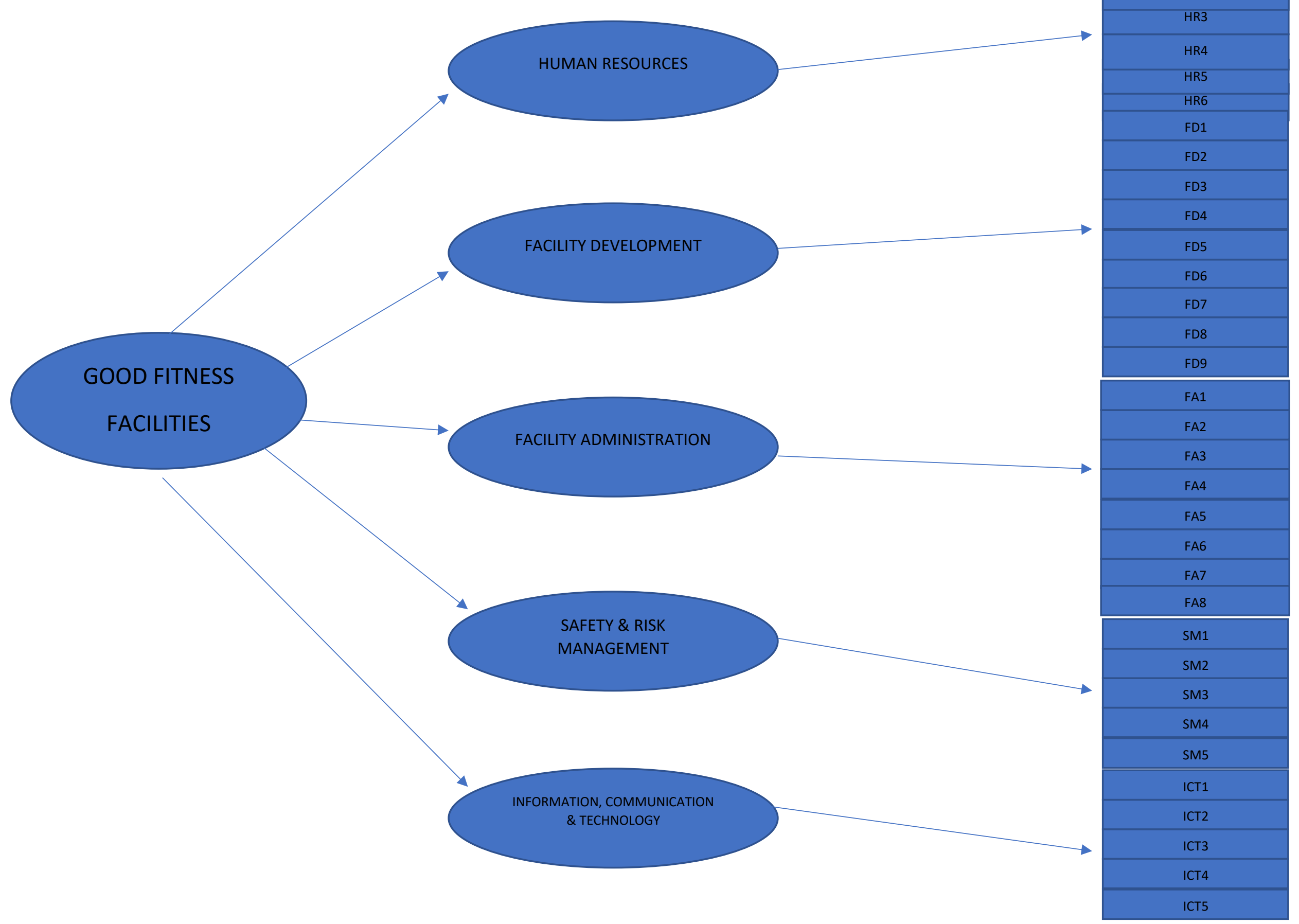




\section{Discussion/Conclusion}

The fitness industry is emerging and the demand by customers had also increased, it is always a priority to serve the best for the customers in developing a good rapport within the industry. The development of MFFGS is surely a steppingstone in providing the fitness facilities operator guided guidelines on establishing a good fitness facility. Based on the validity and reliability of the instrument, it is proven that all seven factors were important in determining a good fitness facility. These days, ranking or grading can be very important especially in the area that involves the life and safety of the public. Grading schemes have become a popular way to convey the quality of public services accessibly and concisely (Meltzer et al., 2015). By providing the MFFGS it will be an aid to the fitness facilities operators to acknowledge the demand by their customers and stakeholders. Not only that, but this will also help provide a safe fitness engagement environment for the fitness practitioner. Meltzer et. (2015), also mentioned that grading is also conveying information upon the quality of services or goods including the policies, public education, and public health. In addition, this grading system will help in improving the quality of services and goods. This was aligned by a statement from Yusof and Popa (2018), due to the increment in participation in fitness activities, providing quality service in a fitness facility is one important element to influence member retention and the quality of service in a fitness facility must be met or exceeds the expectations to satisfy users. Not only that but the performance of a fitness center can also be matched to the customer's needs and wants or exceed it and the performance measurement is through the service quality provided (Yusof \& Popa, 2018). Through this, an advantage can be gained from any competitive organization, companies or even another fitness centre (Kordi, 2015). Overall, this study is believed to create a new paradigm in determining and classifying a fitness facility. This study works as a guideline for the fitness facilities operators, users and it may also work as a reference for policy makers in providing an excellent service to the stakeholders. The instrument developed can be a good extension of knowledge in fitness facility management.

\section{References}

Atkin, B., \& Brooks, A. (2015). Total Facility Management. Wiley-Blackwell; 4th edition (February 13, 2015)

Cianfanelli, C., Valeriani, F., Santucci, S., Giampaoli, S., Gianfranceschi, G., Nicastro, A., Spica, V. R. (2016). Environmental Quality in Sports Facilities: Perception and Indoor Air Quality. Journal of Physical Education and Sports Management, 3(2). https://doi.org/10.15640/jpesm.v3n2a4

International Health, Racquet, and Sports Club Association (IHRSA). (2019). The 2019 Annual Global Report.

Kordi, M. (2015). Service quality: any link to customers decision making. Albertiana, 82, 1-6

Ong, D. L. T., \& Yap, W. X. (2017). The Impact of Fitness Center Servicescape on Individual Behavior: The Mediating Role of Emotional Response. Journal of Global Sport Management, 2(2), 128-142. https://doi.org/10.1080/24704067.2017.1314177

Ong, L. T. (2015). Enhancing the experience of needs satisfaction through service engagement: $A$ case of commercial fitness centers in Malaysia. Journal of Global Scholars of Marketing Science: Bridging Asia and the World, 25(2), 109-121.

Thaler, R. H., \& Cass, R. S. (2009). Nudge: Improving Decisions About Health, Wealth, and Happiness. New York: Penguin Books. 
INTERNATIONAL JOURNAL OF ACADEMIC RESEARCH IN PROGRESSIVE EDUCATION AND

DEVELOPMENT

Vol. 10, No. 3, 2021, E-ISSN: 2226-6348 @ 2021 HRMARS

Yusof, A., Joseph, J., \& Shah, P. M. (2017). Customer's expectation, perception and satisfaction with service quality of a fitness center in Malaysia. $146 \sim$ International Journal of Physical Education, Sports and Health, 4(1), 146-150. Retrieved from www.kheljournal.com 